\title{
PEMBERDAYAAN POTENSI MASYARAKAT DESA MATESIH KABUPATEN KARANGANYAR (PEMANFAATAN KAIN FLANEL)
}

\author{
Yenni Khristiana ${ }^{1)}$ \\ Andri Octaviani ${ }^{2)}$ \\ Rina Ani Sapariyah ${ }^{3)}$ \\ STIE Adi Unggul Bhirawa Surakarta \\ Email: yennikristi2@gmail.com
}

\begin{abstract}
Abstrak
Pengabdian telah dilaksanakan diKelurahan Matesih Kecamatan Matesih Surakarta. Pelaksanaan pengabdian selama 6 bulan dari bulan September 2017 sampai bulan Maret tahun 2018. Tujuan dari pengabdian masyarakat ini adalah untuk memberikan pelatihan pembuatan aneka kerajinan dari kain flanel dimana memanfaatkan kain yang sudah tidak terpakai lagi. Selain itu, pelatihan ini juga dapat mendorong untuk membuka jiwa kreativitas dan jiwa wirausaha baru di bidang produk ramah lingkungan. Hasil dari kegiatan pengabdian ini dapat memberikan manfaat bagi peserta dan mudah untuk diterapkan oleh ibu - ibu Pembinaan Kesejahteraan Keluarga di Kelurahan Matesih Kecamatan Matesih Karanganyar dalam pemanfaatan kain flanel, peningkatan animo ibu-ibu PKK desa Matesih saat dilakukan sesi Tanya jawab dan Konsultasi yang berkelanjutan kepada Tim Pengabdian kepada Masyarakat Sekolah Tinggi Ilmu Ekonomi Adi Unggul Bhirawa (STIE AUB) Surakarta secara tidak terjadwal.
\end{abstract}

Kata Kunci: Kelurahan Matesih, Kain Flanel, Kewirausahaan, Produk ramah lingkungan.

\section{A. PENDAHULUAN}

Kerusakan lingkungan yang terjadi saat ini disebabkan oleh eksploitasi sumberdaya alam dan konsumsi yang berlebihan dikarenakan terjadinya pertumbuhan ekonomi yang cepat. Pemanasan global, penipisan lapisan ozon dan degradasi lingkungan (tanah, udara dan air) merupakan konsekuensi yang harus ditanggung akibat kerusakan lingkungan yang dapat mengancam kesehatan dan jiwa.Saatini, konsumen secara bertahap mengubah sikap dan perilaku mereka dalam hal konsumsi, karena kerusakan lingkungan yang sudah terjadi. Jika pemasar dan pembuat kebijakan publik sadar untuk mengurangi perilaku negatif yang dapat merusak lingkungan, maka diperlukan sebuah pemahaman yang lebih mendalam tentang hubungan antara perilaku konsumsi dan perhatian akan kerusakan lingkungan. Konsumen dapat mengubah pola pembelian ke produk yang ramah lingkungan ketika kekhawatiran akan kerusakan lingkungan meningkat.

Permasalahan lingkungan yang sering terjadi dewasa ini telah menjadi permasalahan yang mengancam, tidak hanya kelangsungan hidup dari makhluk hidup yang ada pada satu wilayah, tetapi juga mengancam kelangsungan hidup seluruh makhluk hidup yang ada di bumi ini. Oleh karena itu, dibutuhkan peran aktif dari seluruh elemen masyarakat untuk menyelesaikan permasalahan lingkungan yang ada. Sampah merupakan permasalahan lingkungan yang sangat komplek karena akan berdampak pada permasalahan ekonomi, politik dan sosial budaya. Dan 
dalam pengelolaannya kini menjadi masalah yang kian mendesak hampir di seluruh wilayah di Indonesia, sebab apabila tidak dilakukan penanganan yang baik akan mengakibatkan terjadinya perubahan keseimbangan lingkungan yang merugikan dan tidak diharapkan sehingga dapat mencemari lingkungan baik terhadap tanah, air dan udara. Karena itu, untuk mengatasi masalah pencemaran tersebut diperlukan penanganan dan pengendalian terhadap sampah. Penanganan dan pengendalian akan menjadi semakin kompleks dan rumit dengan semakin banyaknya jenis maupun komposisi dari sampah sejalan dengan semakin majunya kebudayaan. Pandangan dan pola hidup manusia pun mulai bergeser seiring dengan meningkatnya kepedulian dan kesadaran terhadap lingkungan. Hal tersebut dibuktikan dengan adanya tuntutan bagi para pelaku bisnis untuk melakukan tanggung jawab lingkungan (environmental responsibility), sehingga timbul pola 2 pendekatan aktivitas bisnis yang berbasis kelestarian lingkungan (Muslim,2011).

Pada zaman yang serba modern ini,banyak orang yang menghabiskan uang hanya untuk membeli produk-produk atau aksesoris sebagai pelengkap kebutuhan sekunder manusia. Sebenarnya sangat banyak benda atau bahkan limbah di sekitar kita yang dapat dimanfaatkan untuk membuat berbagai kerajinan atau produk yang kreatif,inovatif dan memiliki nilai jual ekonomis. Salah satunya adalah pemanfaatan limbah nabati untuk pembuatan produk tempat pensil. Limbah nabati yang digunakan berupa kulit jagung . Kemudian produk ini juga menggunakan limbah dari minuman botol sebagai bahan dasarnya.

Pemanfaatan limbah sebagai bahan utama produk ini sebagai bentuk dukungan terhadap program daur ulang yang banyak digencarkan oleh pemerintah maupun organisasi-organisasi masyarakat. Selain itu memanfaatan limbah dapat menambah dan mengembangkan kreativitas wirausaha dan mengurangi dampak pencemaran lingkungan yang disebabkan oleh limbah tersebut. Sehingga pemanfaatan limbah sebagai bahan dasar pembuatan produk ini memiliki banyak manfaat untuk pendiri maupun untuk lingkungan sekitarnya.

\section{Dalam upaya penanganannya} pemerintah membutuhkan kesadaran dan peran serta masyarakat dalam pelaksanaan pengelolaan sampah, karena pelestarian lingkungan adalah kewajiban kita semua. salah satu penangannanya adalah penerapan program 3R (Reduce, Reuse dan Recycle). Contohnya kertas bekas, kain bekas dan bungkus kopi yang sudah tak terpakai bisa kita olah dengan cara mendaur ulang/ recycle menjadi sesuatu barang yang mempunyai manfaat dan nilai ekonomi.

Junaedi (2005) mendefinisikan, produk hijau (Green product) adalah produk yang tidak berbahaya bagi manusia dan lingkungannya, tidak boros sumber daya, tidak menghasilkan sampah berlebihan, dan tidak melibatkan kekejaman pada binatang Green product harus memper timbangkan aspek-aspek lingkungan dalam siklus hidup produk sehingga dapat meminimalkan dampak negatif terhadap alam. Upaya minimalisasi tersebut untuk mendorong semua pihak agar berperan dalam pengembangan teknologi menuju produk ramah lingkungan.Pada sektor produksi, berbagai macam cara dapat dilakukan guna menghasilkan suatu produk yang ramah lingkungan yaitu salah satunyadengan menggunakan konsep green productyang berkelanjutan.Intinya, green product adalah upaya untuk meminimalkan limbah proses produksi di samping memaksimalkan produk yang dibuat sekaligus memenuhi syarat ramah lingkungan.

Definisi atau pengertian kewirausahaan sebenarnya sanggat beragam menurut beberapa pendapat.Akan tetapi makna dari pengertian kewirausahaan itu tidak jauh 
berbeda. Kewirausahaan adalah sikap, jiwa, dan kemampuan untuk menciptakan sesuatu yang baru yang sangat bemilai dan berguna bagi dirinya dan orang lain.

Kewirausahaan merupakan sikap mental dan jiwa yang selalu aktif, kreatif, berdaya, bercipta, berkarsa dan bersahaja dalam berusaha dalam rangka meningkatkan pendapatan dalam kegiatan usahanya atau kiprahnya. Kewirausahaan adalah suatu nilai yang diwujudkan dalam perilaku yang dijadikan dasar sumber daya, tenaga penggerak, tujuan, siasat, kiat, proses dan hasil bisnis (Achmad Sanusi, 1974).

Saat ini, produk ramah lingkungan yang ada di pasaran harganya cenderung lebih tinggi dari produk konvensional pada umumnya.Sehingga menjadikan minat pada produk ramah lingkungan cenderung masih rendah. Oleh sebab itu, alangkah baiknya jika konsumen dapat diajarkan membuat sendiri produk ramah lingkungan yang pastinya lebih terjangkau. Untuk pengabdiankepadamasyarakat kali ini, Tim Pengabdian STIE AUB Surakarta akan mengadakan pelatihan kepada ibu-ibu PKK di Kecamatan Matesih Kabupaten Karanganyar. Pelatihan yang akan dilakukan adalah pembuatan kerajinan dari kain flanel dimana memanfaatkan kain yang sudah tidak terpakai lagi. Selain itu, pelatihan ini juga dapat mendorong untuk menumbuhkan jiwa kreativitas danjiwakewirausahaan baru di bidang produk kerajinan ramah lingkungan.

\section{B. METODE PELAKSANAAN}

Sasaran dari Kegiatan Pengabdian Kepada Masyarakat ini adalah ibu - ibu Pembinaan Kesejahteraan Keluarga (PKK) Kelurahan Matesih, Kecamatan Matesih Karanganyar. Program pengabdian kepada masyarakat dilaksanakan berkaitan dengan pelestarian lingkungan dengan meningkatkan minat pada produk ramah lingkungan dan menumbuhkan nilai kewirausahaan dengan memanfaatkan bahan yang ramah lingkungan sehingga lingkungan tetap terjaga.

Kegiatan Pengabdian Kepada Masyarakat ini berbentuk Pelatihan dan Penyuluhan mengenai pentingnya melestarikan lingkungan, salah satunya dengan cara memberikan edukasi menggunakan atau membuat produk ramah lingkungan. Dalam membuat produk ramah lingkungan yaitu aneka kerajinan dari kain flanel, tim pengabdian memberikan contoh dan memperagakan langkah - langkah dalam membuat aneka kerajinan berbahan dasar kain flanel.

INDIKATOR KEBERHASILAN

a. Peningkatan pengetahuan tentang pentingnya kelestarian lingkungan.

b. Peningkatan pengetahuan tentang manfaat produk ramah lingkungan.dan cara memanfaatkan bahan yang sudah tidak terpakai menjadi sesuatu yang berguna.

c. Peningkatan pengetahuan dan ketrampilan tentang cara pembuatan aneka kerajinan berbahan dasar kain flanel.

\section{HASIL DAN PEMBAHASAN}

Kegiatan pelatihan pemberdayaan kain flanel untuk meningkatkan minat terhadap produk ramah lingkungan dilaksanakan selama 6 bulan. Pelaksanaan pelatihan pembuatan aneka kerajinan dari kain flanel dilaksanakan pada saat kegiatan arisan Pembinaan Kesejahteraan Keluarga (PKK). Adapun lokasi pelaksanaan pelatihan bertempat di area Balai Desa yang bertempat di Kelurahan Matesih Kecamatan MatesihKaranganyar. Peserta pelatihan terdiri atas $\mathrm{ibu}-\mathrm{ibu}$ Pembinaan kesejahteraan Keluarga (PKK) Kelurahan Matesih Kecamatan Matesih Karanganyar. Peserta pelatihan yang hadir dalam kegiatan pengabdian kepada masyarakat sekitar 100 orang.

Pada kesempatan tersebut, ketua dan 
anggota tim kegiatan pengabdian pada masyarakat ini menjadi narasumbernya. Kegiatan dimulai dengan pemaparan materi mengenai pengenalan bahan-bahan kerajinan yang ramah lingkungan.Selanjutnya menjaga kelestarian lingkungan dan manfaat produk ramah lingkungan, pelaksanaan pelatihan pembuatan aneka kerajinan berbahan dasar kain flanel seperti (buket bunga) dan peluang kewirausahaan yang bisa didapat.

Narasumber memberikan contoh dan tahapan dalam membuat buket bunga berbahan dasar kain flanel, mulai dari yang berbentuk kain sampai menjadi tas. Berikut ini disajikan tahapan pelaksanaankegiatan :

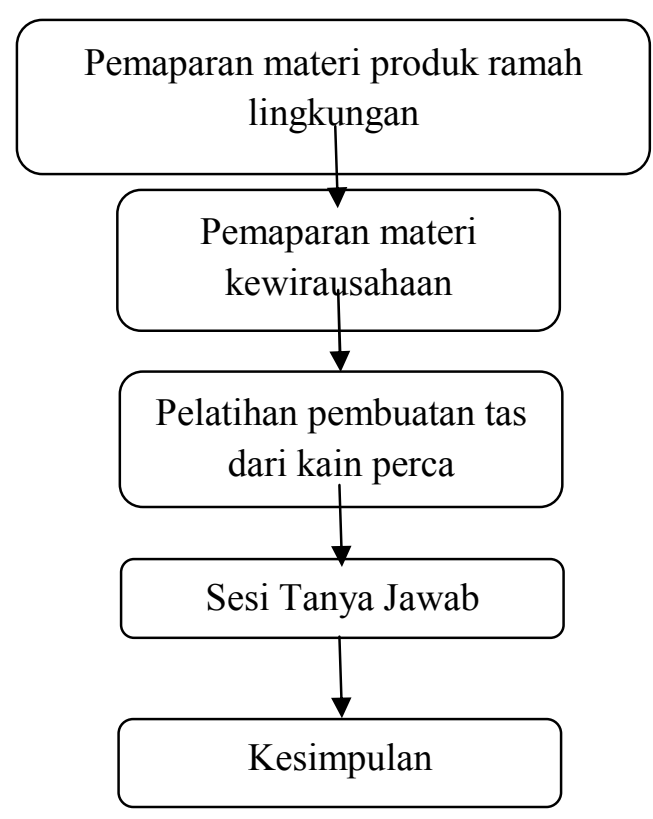

D. PEMBAHASAN

Pelaksanaan kegiatan pengabdian kepada masyarakat tentang pelatihan pembuatan aneka kerajinan kain flanel menunjukkan antusiasme yang sangat tinggi dari peserta ibu - ibu Pembinaan Kesejahteraan Keluarga (PKK) Kelurahan Matesih Kecamatan Matesih Karanganyar. Antusiasme tersebut ditunjukkan dengan banyaknya pertanyaan yang diajukan seputar cara pembuatan buket bunga dari kain flanel. Narasumber berusaha untuk menjawab pertanyaan- pertanyaan tersebut dan memberikan penjelasan yang mendalam mengenai tema yang ditanyakan.Tim pengabdian kepada masyarakat berharap kendala-kendala yang dihadapi dalam pelatihan pembuatan buket bunga dari kain flanel tidak menyurutkan semangat ibu - ibu Pembinaan Kesejahteraan Keluarga (PKK) dan juga diharapkan dapat menimbulkan jiwa kewirausahaan di kalangan ibu - ibu Pembinaan Kesejahteraan Keluarga di Kelurahan Matesih Kecamatan MatesihKaranganyar.

Menurut pengamatan tim pengabdian kepada masyarakat bahwa selama pelaksanaan kegiatan pelatihan tersebut, produk ramah lingkungan masih dirasa awam oleh ibu - ibu Pembinaan Kesejahteraan Keluarga (PKK) di Kelurahan Matesih Kecamatan Matesih Karanganyar.

\section{E. EVALUASI}

Keberhasilan pelaksanaan program pengabdian masyarakat ini dilihat dari dua indikator yaitu :

a. Respon positif dari peserta yang hadir dari awal hingga kegiatanberakhir.

b. Mampu memberikan manfaat bagi peserta dan mudah untuk diterapkan oleh ibu - ibu Pembinaan Kesejahteraan Keluarga di Kelurahan Matesih Kecamatan MatesihKaranganyar.

\section{F. KESIMPULAN DAN SARAN}

Berdasarkan hasil dan pembahasan kegiatan pengabdian kepada masyarakat yang telah diuraikan sebelumnya, dapat disimpulkan bahwa :Pemahaman peserta tentang pentingnya menjaga kelestarian lingkungan dan produk ramah lingkungan semakin tinggi setelah mengikuti pelatihan pembuatan kerajinan buket bunga dari kain flanel.Kemampuan peserta pelatihan pembuatan kerajinan buket bunga dari kain flaneldapat meningkat dan dapat berguna bagi lingkungan sekitar serta dapat 
menumbuhkan nilai kewirausahaan pada ibu-ibu Pembinaan Kesejahteraan Keluarga (PKK) di Kelurahan Matesih Kecamatan MatesihKaranganyar. Oleh karena itu, Penulis menyarankan Penyelenggaraan program pengabdian kepada masyarakat dengan bentuk pelatihan pembuatan kerajinan buket bunga dari kain flanel sangat diperlukan bagi ibu-ibu Pembinaan Kesejahteraan Keluarga (PKK) untuk memberikan ketrampilan baru yang nantinya mengarah ke kewirausahaan sehingga perlu dilakukan secara berkelanjutan.

\section{G. DAFTAR PUSTAKA}

Adi Penawan, 2010, Arah Keberlanjutan PNPM Mandiri, Makalah Seminar Nasional Pada Rangkaian Acara Temu Nasional ke-3 PNPM Mandiri 2010, Jakarta, 21 - 23 Oktober 2010.

Ahmad Sanusi. (1974). Menelaah Potensi Perguruan Tinggi Untuk Membina Program Kewirausahaan dan Mengantar Pewiarusaha Muda.Makalah Seminar. Bandung: IKIP.

Anderson, Elisabeth T, (2007). Buku ajar keperawatan komunitas: teori dan praktek. Jakarta:EGC.

A.M.W. Panarka dan Vidyandika Moeljarto,1996, Pemberdayaan (Empowerment), Penyunting : Onny S. Prijono dan A.M.W. Pranarka, Pemberdayaan Konsep, Kebijakan dan Implementasi, CSIS, Jakarta.

Chen, T.B dan Chai, L.T. 2010. Attitude Toward The Environment and Green Product. Management Science and Engineering. 4(2), pp: 27- 39.

Chen, Ying-Hueih., I-Chieh, Hsu, dan ChiaChen, Lin. 2010. Website Attributes that Increase Consumer Purchase Intention: A Conjoint Analysis. Journal ofBusiness Research 63, 1007-1014.

http://eprints.uny.ac.id/7803/3/BAB\%20207404244051.pdf
Hendro,Ir.M.M.(2011). Dasar-dasar kewirausahaan. Jakarta: Erlangga

Heri Sulistyanto, dan Edy Wiyono. 2008. Ilmu Pengetahuan Alam untuk SD/MI Kelas V. Jakarta: Pusat Perbukuan Departemen Nasional.

Junaedi, S.M.F. (2005). Pengaruh Kesadaran Lingkungan pada Niat Beli Produk Hijau: Studi Perilaku Konsumen Berwawasan Lingkungan. Jurnal Manajemen dan Bisnis 9 (2), hal 189-201

Kong, Wilson, Harun, Amran. Sulong, Rini Suryati. Lily, Jaratin. 2014. The Influence of Consumers' Perceprion of Green Products on Green Purchase Intention International Journal of Asian Social Science, 4(8): 924 939.

Laksita, D. A. dan Wardana, I Made. 2015. "Peran Sikap Dalam Memediasi Pengaruh Kesadaran Terhadap Niat Beli Produk Ramah Lingkungan". E-Jurnal Manajemen Universitas Udayan Bali_Indonesia, Vol. 4, No. 7, pp: 1902-1917.

Muslim, Ahmad.. Peranan Konsumsi dalam Perekonomian Indonesia dan Kaitannya dengan Ekonomi Islam, Jurnal Al-Azhar Indonesia Seri Pranata Sosial,Vol. 1, No. 2 , 2011.

Nugroho, Riant. 2008. Public Policy. PT Elex Media Komputindo: Jakarta.

Paryanto, 2015, Selamatkan Asset PNPM, UPK Harus Berbadan Hukum, Jurnal Warga, http://www.karanganyarkab.go.id/20150224 Iselamatkan-asset-pnpm-upk-harusberbadan-hukum/

http://www.kemenperin.go.id/artikel/8810/Pasar -Global-Produk-Ramah-Lingkungan

Sulistyani, Ambar T\& Rosidah. 2003. Manajemen Sumber Daya Manusia : Konsep, Teori dan Pembangunan dalam Konteks Organisasi Publik. Yogyakarta : Graha Ilmu.

Sulistiyani, A.T. 2004. Kemitraan dan ModelModel Pemberdayaan. Jogjakarta.:Gava Media. 
Sumodiningrat, Gunawan. 2007. Pemberdayaan Sosial. Buku Kompas: Jakarta.

Suharto, Edi. 2009. Membangun Masyarakat Memberdayakan Rakyat: Kajian Strategis

Pembangunan Kesejahteraan Sosial dan Pekerjaan Sosial. PT. Refika Aditama: Bandung.

Thomas W Zimmerer, Norman M Scarborough, Kewirausahaan dan Manajemen Usaha Kecil , Salemba empat, 2008. Sulistiyani, A.T. 2004.

Kemitraan dan Model-Model

Pemberdayaan.

Jogjakarta.:Gava Media.

Artikel dan Makalah :

Heri Wahyu Supartini. Skripsi. 2006. Implementasi Kebijakan Sistem Jaminan Mutu UGM. Sriningsih.Skripsi. 2008. Kinerja Implementasi Program Jaminan Sosial Tenaga Kerja untuk Pelaku Sektor Informal UGM 